Many other social and economic attributes can be found in the NES collection as well: occupation and employment, income, age, race, gender, ethnic origin, family composition and living arrangements, religious affiliation, and educational attainment, to name a few.

\section{Obtaining the ANES CD-ROM}

Faculty, staff, and students at Inter-university Consortium for Political and Social Research (ICPSR) member institutions can gain access to the ANES CD-ROM in two ways: by contacting their campus's ICPSR official representative, or through purchase of an individual copy of the disc directly from
ICPSR. ICPSR has made available several copies of the ANES CDROM to each of the official representatives at its over 300 member institutions. Individuals at these member institutions may purchase personal copies of the CD-ROM at a discount. Purchase of the ANES CD-ROM by individuals not located at ICPSR member institutions is also possible.

Individuals interested in ordering the CD-ROM can download an electronic copy of the order form from the ICPSR Gopher (gopher. icpsr.umich.edu) or from the NES World Wide Web homepage (http:// www.umich.edu/ nes/). Individuals can also fax the ICPSR at 313-7648041 , or contact it by mail at
ICPSR, P.O. Box 1248, Ann Arbor, Michigan, 48106-1248.

The CD-ROM is a collaborative effort between the NES and ICPSR made possible by funding provided by the National Science Foundation as part of its long-term support of the National Election Studies.

\section{About the Author \\ Erik W. Austin is director of archival devel- opment at ICPSR and executive director of the Social Science History Association.}

Steven J. Rosenstone is the NES principal investigator and a professor of political science at the University of Michigan.

\title{
Pi Sigma Alpha, the Political Science Honor Society: Seventy-five Years of Change and Growth
}

\author{
David B. Magleby, President, Pi Sigma Alpha
}

i Sigma Alpha, the political science honor society, is 75 years old this year. Over the past few years the society has initiated a series of new programs and activities intended to recognize excellence in political science students, facilitate the creation of new chapters and

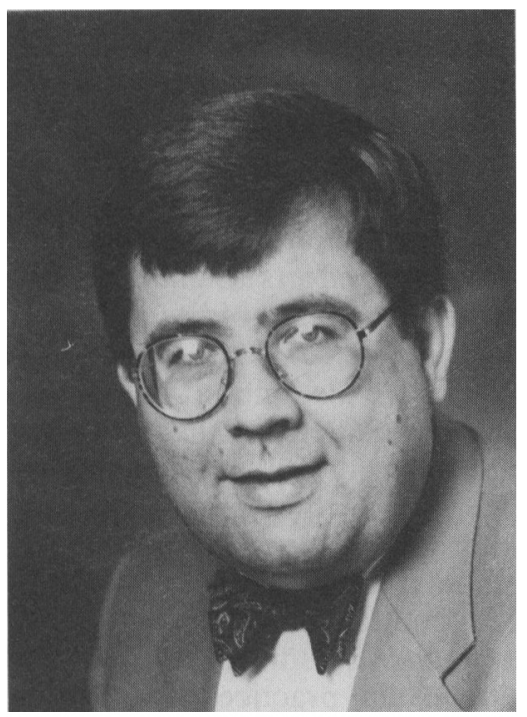

David B. Magleby the revitalization of old chapters, encourage all chapters to involve students in meaningful activities related to the discipline, and foster the development of the discipline of political science.

\section{History}

Pi Sigma Alpha was founded in 1920 at the University of Texas with the purpose of bringing together students and faculty interested in the study of government and politics. Professor C. Perry Patterson was an early leader of the first chapter and served as president of the society from 1920 until 1932. The success of Pi Sigma Alpha at the University of Texas prompted other universities to adopt chapters. The University of Kansas and the University of Oklahoma established chapters in 1922. In March of that year the society held its first national convention at the University of Oklahoma.

Growth in the number of chap- ters accelerated following the Second World War. Today there are 463 chapters, with at least one chapter in each of the 50 states and the District of Columbia plus, as of this year, Guam. Pi Sigma Alpha is the third largest member of the Association of College Honor Societies. The growth in new chapters is accelerating; 66 schools have been granted charters in the past five years and 24 in 1994-95 alone. Most existing chapters are actively recruiting new members; over the past two years, $87 \%$ of chapters registered new initiates with the national office.

\section{Forming a Chapter}

There are several requirements for establishing a new chapter. The institution itself must

a. be fully accredited;

b. confer the B.A. degree in its own name;

c. recruit its own faculty; and 
d. have a student body of at least 500 full-time students.

The political science department must

a. have at least three full-time political science Ph.D.'s on its faculty and a faculty with a majority of Ph.D.'s. In departments of 20 or more members, $60 \%$ of the faculty must have doctorates in political science;

b. determine its own curriculum for the political science major without needing approval from another institution;

c. have at least 15 full-time political science majors; and

d. enable a student to obtain a degree in political science without having to take supplemental work at another institution.

Schools wishing to establish a chapter must go through a petitioning process. The final decision regarding the admission of a petitioning institution rests with Pi Sigma Alpha's member chapters. A detailed information packet for starting a chapter is available from the National Office.

As an honor society our first priority is to encourage and recognize excellence in students and faculty. Students studying government, political science, international relations, and public administration are eligible for membership. Faculty in the same fields and specializations are also eligible for membership. Honorary membership is also bestowed on persons who have made valuable contributions to political science or government. Students attain membership in Pi Sigma Alpha by meeting high standards of scholarship and academic distinction in political science courses and in their overall course of studies. The minimum academic standards for admission to the honor society set by the national constitution include 25 quarter hours or 10 semester hours of work in political science including at least one upper-division course, a 3.0 GPA in political science courses and an overall GPA that places the student within the top third of his or her college class. Individual chapters may and frequently do make the requirements more stringent.

\section{Programs}

To recognize excellence in students, the society this year established the Pi Sigma Alpha Scholarship, a grant of $\$ 1,250$ to a member entering a graduate program in political science. In future years the society hopes to increase both the number of Pi Sigma Alpha scholarships and the stipend.

The first Pi Sigma Alpha Scholarship winner is Allison Spitzer, a recent honors graduate of the University of Florida. Ms. Spitzer was the president of the University of Florida's Beta Gamma chapter and is now beginning a graduate program in public administration at Florida Atlantic University.

Having a vibrant Pi Sigma Alpha chapter requires interested students, an attentive advisor, and a supportive faculty and department chair. Active chapters exist at schools of all sizes. Some have only a score of members, others have many times that number. To recognize outstanding chapters, the Pi Sigma Alpha Executive Council recently created Best Chapters Awards. Each year, the national office will honor three outstanding chapters in each of three enrollment categories (schools with enrollment under 6,000 ; from 6,000 to 15,000 ; and over 15,000 ) with a prize of $\$ 250$. The awards are based on the information provided in the chapter's annual report to the national office.

The program of exemplary $\mathrm{Pi}$ Sigma Alpha chapters goes beyond the annual initiation ceremony to include activities that foster student and faculty interaction, student scholarship, and community service. Chapters are encouraged to become an integral part of the political science department in organizing and implementing extracurricular activities related to public affairs. Chapters can compete for "seed money" to facilitate some of these activities through the Chapter Activity Grants program run by the national office. Here are some examples of chapter activities that have been successful in the past few years:

- Freshman mentor program. Many beginning students feel lost and bewildered by the transition to college. Some chapters have implemented a "freshman buddy" program that matches advanced students with beginning students. This program teaches the new students important college survival and interpersonal skills. It also serves as a useful recruiting mechanism for future chapter members and leaders.

- Current events discussion at a senior citizens center. Some chapters try to give something back to their local community by organizing a service project of some kind. One chapter organizes a current events class at a nearby senior citizens center. Discussions are led by teams of undergraduates who gather up surplus periodicals from the department and deposit them at the center prior to the class. The question and answer format engages college students and retirees in mutually beneficial discussion about the subject of the students' major field of study.

- Guest speakers on campus. Many chapters sponsor debates and speakers at their universities. These occasions often broaden student interest in the major and the Pi Sigma Alpha chapter. The Chapter Activity Grants program is a possible source of funding to help defray the costs of these speakers.

- Publication of a student journal. Publication of a journal of the best undergraduate papers can not only recognize good research and writing but also teach students editorial skills. Several chapters have received grants to conduct writing contests and publish a student journal on their campus.

- Hosting a statewide conference for undergraduate political science majors. Students often propose to have political science activities with students from nearby colleges and universities. These can include mock legislatures, guest speakers, career fairs, or 
meetings at which students present papers or conduct roundtable discussions. Much of the work of organizing this activity is done by the students, but the involvement of an active faculty advisor is also essential.

- Other chapter activities include Thanksgiving food drives, international affairs lecture series, chapter newsletters, law school and LSAT forums, and visits to the state legislature.

The national office has $\$ 25,000$ budgeted to distribute in grants to local chapters to undertake these kinds of activities. To receive a grant of up to $\$ 2,000$, individual chapters must submit a grant proposal to the national office which outlines the proposed activity and budget. Grants are awarded on a competitive basis by an awards committee appointed by the executive director. The 1994 awards are listed below.

Chapter activity often is the result of an interested and attentive faculty advisor. Advisors, however, often are not fully recognized for their contribution to the academic

\section{A 1994 Chapter Awards}

Brigham Young University

Student essay contest and annual banquet

\section{Canisius College}

Political science career fair

\section{Georgetown University}

High school scholarship essay contest

Johns Hopkins University

Student paper contest; luncheon lecture series

Marist College

Organizing seminar on state government for high school seniors

New Mexico State University

Student political science journal and awards banquet

Ohio State University

Statewide $\Pi \Sigma$ A conference on Russian-U.S. relations

Oregon State University

Two student essay contests and awards banquet

Purdue University Calumet

Lecture series on public service; essay contest; banquet

Saint Olaf College

Lecture series on "Culture and Politics"

San Jose State University

Banquet; admission fee for disadvantaged students

\section{Southern University}

Essay contest and awards banquet

\section{St. Joseph's University}

Subsidy for annual induction banquet

University of Maryland, Baltimore County

Lecture series on international affairs

University of Maryland, College Park

Job/internship fair for politics majors

\section{University of Montana}

Symposium on the balanced budget amendment

University of South Carolina, Spartanburg

High school essay contest

Utah State University

Political science student orientation activities; student advising

workshops; networking system for graduating seniors

University of Wisconsin, Madison

Foreign affairs forum; essay contest; weekly discussion group;

banquet subsidy climate of the department. Too often, being chapter advisor is a task piled on top of other committee and administrative work and often goes unnoticed. As Pi Sigma Alpha Executive Director James I. Lengle has noted, "Chapter advisors are our strongest link to our student members, and the level of leadership they provide within their chapters is the most important stimulus to student interest and involvement in the society." The society's executive council, therefore, has chosen to recognize outstanding chapter advisors. The new award consists of a cash prize of $\$ 1,000$, a certificate, recognition in the Pi Sigma Alpha Newsletter and in PS: Political Science \& Politics, and a letter of commendation sent to the advisor's university or college.

Pi Sigma Alpha has long sponsored best paper awards at professional political science meetings as a way of recognizing scholarship within the discipline. Building on this idea, the society is initiating an award for best undergraduate and graduate student papers. Departments with chapters may nominate one graduate and one undergraduate student paper each year. Departments are encouraged to organize a nominating committee to screen papers. The winner of the best graduate student paper will receive an award of $\$ 200$; the best undergraduate paper will receive $\$ 150$; and two runners-up will receive $\$ 100$ each. Winners of the best chapter advisor award, best chapter awards, student scholarship, and student paper awards will be recognized at Pi Sigma Alphasponsored events at the American Political Science Association annual meeting.

The Pi Sigma Alpha Newsletter, published in October, January, and April, assists chapter advisors and student leaders. The newsletter offers helpful information on chapter grants, programs, and activities that are happening at other schools. It provides timely reminders of nomination deadlines, format for annual reports on chapter activities and grants, and general news of the society. Eight copies of the newsletter are mailed to department chairs with a request that they be 
distributed to the chapter advisor and student leaders. If, as chapter advisors, you are not receiving your copies of the Newsletter, please contact your chair or the national office. The Pi Sigma Alpha Newsletter is edited by John Tierney of Boston College.

In 1991, Pi Sigma Alpha began a lecture series at the Annual Meetings of the American Political Science Association to provide political scientists an opportunity to hear and question a major public figure.

The first speaker was former Secretary of Defense Dick Cheney. Subsequent speakers have included Senator Daniel Patrick Moynihan and Ira Magaziner, White House Senior Advisor for Policy Development. This year's speaker is William Kristol, editor and publisher of The Weekly Standard. Mr. Kristol formerly headed the Project for the Republican Future and was a prominent strategist behind the Republican congressional victory in 1994.
Pi Sigma Alpha also helps underwrite the costs of special sessions at regional and state political science meetings. It will contribute up to $\$ 1,000$ toward the expenses and honorarium of a speaker at a regional meeting and $\$ 500$ toward the same costs at a state meeting. The speaker must be a prominent political leader or commentator who will deliver a substantive lecture of benefit to social scientists.

\section{Initiatives}

The best chapter awards, chapter advisor awards, scholarships, best student paper, and the expansion of the chapter awards program result from the transformation of $\mathrm{Pi}$ Sigma Alpha at the national level. Past presidents Sid Wise, Bob Huckshorn, and Naomi Lynn directed the organizational overhaul. Karl Cerny, and now James I. Lengle, provided strong leadership as executive directors during this time of revitalization. The Executive Council of Pi Sigma Alpha will continue to expand the society's activities and visibility and welcomes suggestions on how to better accomplish its objectives.

Pi Sigma Alpha's national office relocated in 1991 to its current office in the APSA headquarters building. This move has facilitated a closer working relationship between Pi Sigma Alpha and APSA. The national office is ably staffed by Nancy McManus and is open from 9:45 a.m. until 2:45 p.m. Monday through Thursday. Questions about chartering new chapters or other Pi Sigma Alpha-sponsored activities can be directed to the national office.

Pi Sigma Alpha, 1527 New Hampshire Avenue, N.W., Washington, D.C. 20036, Phone: (202) 483-2512, Fax: (202) 483-2657, Internet: pisigmaa@guvax.georgetown.edu, Bitnet: pisigmaa@guvax.bitnet.

\section{Pi Sigma Alpha Executive Council}

President: David B. Magleby, Brigham Young University President-elect: John Bibby, University of Wisconsin-Milwaukee Past President: Naomi B. Lynn, Sangamon State University Past President: Robert J. Huckshorn, Florida Atlantic University Executive Director: James I. Lengle, Georgetown University Newsletter Editor: John Tierney, Boston College

Sheila Ards, University of Minnesota Jon Bond, Texas A\&M University David Canon, University of Wisconsin-Madison Clayton Clemens, College of William and Mary Henry Flores, St. Mary's University Calvin Jillson, University of Colorado Charles O. Jones, University of Wisconsin-Madison William Keefe, University of Pittsburgh Susan MacManus, University of South Florida Joseph McCormick, Howard University Margaret Scranton, University of Arkansas at Little Rock Alan Shank, SUNY Geneseo James Thurber, The American University 